\title{
Path Analysis of Climatic Factors Affects the Population of American Bollworm, Helicoverpa armigera (Hubner) Lepidoptera - Noctuidae in Cotton
}

\author{
Yogesh Patel* and V. K. Garg \\ Jawaharlal Nehru Agriculture University, College of Agriculture \\ Ganj-Basoda, Distt. Vidisha-464221 M.P. India \\ *Corresponding author
}

\section{Keywords \\ Cotton, American bollworm, Weather, Population dynamics}

\section{Article Info}

Accepted:

12 March 2020

Available Online:

10 April 2020

\section{A B S T R A C T}

The Path analysis of certain climatic factors affects the population of American Bollworm (ABW), Helicoverpa armigera (Hubner) Lepidoptera -Noctuidae in Cotton was assessed at the Jawharlal Nehru Krishi Vishwa Vidhyalaya, Cotton Research Station, Khandwa M.P. The perusal of data on the population of American bollworm, Helicoverpa armigera revealed that the American bollworm, Helicoverpa armigera larvae was first observed during the $29^{\text {th }}$ SMW i.e. III week of July. The population of ABW larvae showed increasing trend between $29^{\text {th }}$ to $36^{\text {th }}$ SMW and attained peak (24.01 larvae) during $36^{\text {th }}$ SMW i.e. IInd week of September and remained active up to 1st SMW i.e. Ist eek of January. The weather condition prevailed during peak population of $\mathrm{ABW}$ larvae viz. maximum temperature, minimum temperature, morning relative humidity, evening relative humidity, sunshine hours, wind velocity, rainfall and rainy day were $34.60^{\circ} \mathrm{C}, 26.15^{\circ} \mathrm{C}, 80.97 \%, 50.65 \%, 8.38$ hours per day, $4.80 \mathrm{kmph}, 21.50 \mathrm{~mm}$ and 1.50 days respectively. The correlation studies between $\mathrm{ABW}$ population and weather factors revealed that the ABW larva population had a significant positive correlation with maximum temperature and minimum temperature. The multiple coefficient value between the ABW population and group of variable clearly indicated that $51.70 \%$ change in $\mathrm{ABW}$ population were affected by maximum temperature, minimum temperature, morning relative humidity, evening relative humidity, sunshine hours, wind velocity, rainfall and rainy days respectively. The Path coefficient analysis of different factors revealed that minimum temperature had positive and high direct effect followed by morning relative humidity, sunshine hours and evening relative humidity respectively. The further revealed that the positive indirect effect of high magnitude of minimum temperature was obtained via, sun shine hours and evening relative humidity respectively. Positive indirect effect of morning relative humidity was obtained via wind velocity, evening relative humidity, sunshine hours and maximum temperature. Positive indirect effect of sunshine hours was obtained via minimum temperature, rainfall, rainy days and morning relative humidity. Positive indirect effect of evening relative humidity was obtained via morning relative humidity and minimum temperature.

\section{Introduction}

Cotton is the most valuable textile fiber produced and utilized in the world from prehistoric times. It accounts for 50 per cent of the total world production of textile fiber and is commercially cultivated in 111 countries on an area of 33.4 million ha accounting for 59,726 thousand metric tones of cotton. India is one of the major producers of cotton in the world with the largest acreage, which is almost one fourth of world 
area. The production share is however, only 13.5 percent ranking third in the world. The production and productivity of cotton is highly influenced by biotic and abiotic factors. Amongst various key factors responsible for poor yield of cotton in India, the damage caused by large number of insect pests during different stages of crop growth are of prime importance. Several insect pests ravage it, which causes drastic reduction in the yield. Rainwater (1952) remarked that cotton plant is specially tailored for insect.

About 1326 insects and mites from all over the world (Hargreaves 1948). Cotton constituting 4 per cent of gross cropped area in India consumes more than 45 per cent of insecticide share accounting for 40 per cent total production cost (Ravindra et al., 2004). This fact signifies the impact of insect pests and the increased agro chemical use in cotton production.

\section{Materials and Methods}

The population dynamics of American Bollworm (ABW), larvae, Helicoverpa armigera (Hubner) Lepidoptera -Noctuidae in relation to environmental factors was assessed at the Jawharlal Nehru Krishi Vishwa Vidhyalaya, Cotton Research Station, Khandwa M.P. The Cotton, Hirsutum variety JK-4 was sown in observation plot of 4000 sq. $\mathrm{m}$ under rain fed condition in black cotton soil during the last week of June in both the year of studied. All the normal agronomical practices recommended for the region were followed for raising the crop. No plant protection measure was taken throughout the crop season. The regular observations on the population dynamics of $\mathrm{ABW}$ larvae was made at weekly interval by randomly selected 25 plants from first appearance of pest until its termination.
At the same time, observations on meteorological parameters viz. minimum and maximum temperature, morning and evening percent relative humidity, total rainfall per week, total rainy days per week, wind velocity (kmph) and sunshine hours per days were recorded daily. Standard meteorological Week (SMW) average of all the data collected for the pest, predator and weather parameters were calculated before statistical analysis. The data thus, collected were computed and subjected to statistical analysis (Panse and Sukhatme, 1985). All the possible correlations, multiple regression and path analysis among the environmental factors were worked out (Gomez, and Gomez 1984).

\section{Results and Discussion}

\section{Population dynamics of $\mathrm{ABW}$}

The data the ABW, Helicoverpa armigera larvae was clearly (Fig. 1) indicated that the first appearance of the pest was observed in the $29^{\text {th }}$ SMW i.e. III week of July and and remained active till Ist 51 SMW (Ist week of Jan). The peak population of ABW was observed (24.01 Larvae / 5 plants) during $36^{\text {th }}$ SMW i.e. IInd week of Sep. The weather condition prevailed during peak population of ABW larvae viz. Maximum temperature, minimum temperature, morning relative humidity, evening relative humidity, sunshine hours, wind velocity, rainfall and rainy day were $34.60^{\circ} \mathrm{C}, 26.15^{\circ} \mathrm{C}, 80.97 \%, 50.65 \%$, 8.38 hours per day, $4.80 \mathrm{kmph}, 21.50 \mathrm{~mm}$ and 1.50 days respectively.

\section{Simple correlation $\&$ regression}

The perusal of data (Table 1) on simple correlation studies between ABW larval population and abiotic and biotic factors revealed that the ABW larvae population had a significant positive correlation with Max Tem (0.469) and Min. tem $(r=0.543)$. 
After $36^{\text {th }}$ SMW there was a decrease in ABW larvae population. It was estimated that every unit decrease Max tem and Min tem. There is decrease in population of $\mathrm{ABW}$ is 1.761 and 0.574 respectively. These finding are agreement with the findings reported by Jawalkar et al., (2004) recorded peak incidence from the 36th to the 41st SMW (2nd week of September to the 2nd week of October). One larval peak was attained in this study which confirm the findings of Pawar et al., (1984) they also noticed one peak of Helicoverpa during August to September. Similar observation have been reported by many other workers Bishnoi et al., (1996), Shahzad et al., (2003), Jawalkar et al., (2004), Mohapatra et al., (2004) and Singh et al., (2005).

\section{Multiple regression analysis}

The multiple regression computed (Fig. 2) with eight parameters i.e. maximum temperature (X1), minimum temperature (X2), morning relative humidity (X3), evening relative humidity (X4), sunshine hours (X5), wind velocity (X6), rainfall (X7), and rainy day (X8), as independent variables and $\mathrm{ABW}$ population as dependent variables was as follows:

$\mathrm{Y}=-51.705+0.373 \mathrm{X} 1+1.002 \mathrm{X} 2+0.295 \mathrm{X} 3$

$+0.004 X 4+0.662 \times 5-0.13 \times 6-0.012 X 7$

$-1.745 \times 8\left(R^{2}=0.517\right)$

The multiple coefficient value between the ABW population and group of variable clearly indicated that $51.70 \%$ change in $\mathrm{ABW}$ population were affected by maximum temperature, minimum temperature, morning relative humidity, evening relative humidity, sunshine hours, wind velocity, rainfall and rainy days respectively.

\section{Path analysis}

The path coefficient analysis of various abiotic with $\mathrm{ABW}$ larvae has been presented in table 2 and figure 3 . The abiotic factor exhibited significant positive correlations with $\mathrm{ABW}$ larvae population were minimum temperature (0.3687). The observations revealed that minimum temperature had positive and high direct effect (1.4428) followed by morning relative humidity (0.2290), sunshine hours (0.0335) and evening relative humidity (0.0306) respectively.

Table.1 Correlation (r) and simple regression (Y) of ABW, H. armigera (Hubner) larvae population with abiotic factors

\begin{tabular}{|l|l|l|l|l|}
\hline S.No. & \multicolumn{1}{|c|}{ Character } & \multicolumn{1}{|c|}{ First Year } & \multicolumn{1}{|c|}{ Second Year } & \multicolumn{1}{c|}{ Pooled } \\
\hline 1 & T MX $\left({ }^{\circ} \mathrm{C}\right)$ & $\begin{array}{l}\mathrm{r}=0.448^{*} \\
\mathrm{Y}=-39.994+1.377 \mathrm{X}\end{array}$ & $\mathrm{r}=0.375$ & $\begin{array}{l}\mathrm{r}=0.469^{*} \\
\mathrm{Y}=-51.893+1.761 \mathrm{X}\end{array}$ \\
\hline 2 & T MN $\left({ }^{\circ} \mathrm{C}\right)$ & $\begin{array}{l}\mathrm{r}=0.560^{*} \\
\mathrm{Y}=-7.406+0.625 \mathrm{X}\end{array}$ & $\begin{array}{l}\mathrm{r}=0.517^{*} \\
\mathrm{Y}=-4.845+0.509 \mathrm{X}\end{array}$ & $\begin{array}{l}\mathrm{r}=0.543^{*} \\
\mathrm{Y}=-6.23+0.574 \mathrm{X}\end{array}$ \\
\hline 3 & RHM $(\%)$ & $\mathrm{r}=-0.047$ & $\mathrm{r}=-0.028$ & $\mathrm{r}=-0.038$ \\
\hline 4 & RHE $(\%)$ & $\mathrm{r}=0.117$ & $\mathrm{r}=0.117$ & $\mathrm{r}=0.117$ \\
\hline 5 & SSH $(\mathrm{hpd})$ & $\begin{array}{l}\mathrm{r}=0.640^{*} \\
\mathrm{Y}=-11.81+2.261 \mathrm{X}\end{array}$ & $\mathrm{r}=-0.306$ & $\mathrm{r}=0.274$ \\
\hline 6 & WV $(\mathrm{kmph})$ & $\mathrm{r}=0.268$ & $\mathrm{r}=0.062$ & $\mathrm{r}=0.177$ \\
\hline 7 & RF $(\mathrm{mm})$ & $\mathrm{r}=-0.130$ & $\mathrm{r}=0.305$ & $\mathrm{r}=-0.325$ \\
\hline 8 & RD $(\mathrm{dpw})$ & $\mathrm{r}=-0.141$ & $\mathrm{r}=0.363$ & $\mathrm{r}=-0.407$ \\
\hline
\end{tabular}

$* \& * *$ Showed significant at $5 \% \& 1 \%$ level of significance respectively 
Table.2 Path coefficient analysis of climatic factor on $\mathrm{ABW}, H$. armigera larvae population

\begin{tabular}{|l|c|c|c|c|c|c|c|c|c|}
\hline & $\begin{array}{c}\text { T MX } \\
\left({ }^{\circ} \mathrm{C}\right)\end{array}$ & $\begin{array}{c}\text { T MN } \\
\left({ }^{\circ} \mathrm{C}\right.\end{array}$ & $\begin{array}{c}\text { RHM } \\
(\%)\end{array}$ & $\begin{array}{c}\text { RHE } \\
(\%)\end{array}$ & $\begin{array}{c}\text { SSH } \\
(\mathrm{hpd})\end{array}$ & $\begin{array}{c}\text { WV } \\
(\mathrm{kmph})\end{array}$ & $\begin{array}{c}\text { RF } \\
(\mathrm{mm})\end{array}$ & $\begin{array}{c}\text { RD } \\
(\mathrm{dpw})\end{array}$ & $\begin{array}{c}\text { Correlation } \\
\text { Coefficient }\end{array}$ \\
\hline T MX & $\mathbf{- 0 . 4 1 8 8}$ & 0.9179 & -0.0004 & 0.0013 & 0.0263 & -0.3847 & 0.0128 & 0.0300 & 0.1744 \\
\hline T MN & -0.2636 & $\mathbf{1 . 4 4 2 8}$ & -0.0029 & 0.0110 & 0.0113 & -0.6558 & -0.1042 & -0.0701 & $0.3687^{*}$ \\
\hline RHM & 0.0007 & -0.0181 & $\mathbf{0 . 2 2 9 0}$ & 0.0145 & 0.0039 & 0.0946 & -0.0569 & -0.0757 & 0.1921 \\
\hline RHE & -0.0173 & 0.5199 & 0.1083 & $\mathbf{0 . 0 3 0 6}$ & -0.0042 & -0.4140 & -0.0876 & -0.0841 & 0.0516 \\
\hline SSH & -0.3285 & 0.4887 & 0.0267 & -0.0038 & $\mathbf{0 . 0 3 3 5}$ & -0.1648 & 0.0702 & 0.0658 & 0.1877 \\
\hline WV & -0.1918 & 1.1262 & -0.0258 & 0.0151 & 0.0066 & $\mathbf{- 0 . 8 4 0 1}$ & -0.0936 & -0.0365 & -0.0399 \\
\hline RF & 0.0274 & 0.7694 & 0.0667 & 0.0137 & -0.0120 & -0.4026 & $-\mathbf{- 0 . 1 9 5 3}$ & -0.1492 & 0.1180 \\
\hline RD & 0.0615 & 0.4945 & 0.0848 & 0.0126 & -0.0108 & -0.1498 & -0.1425 & $\mathbf{- 0 . 2 0 4 6}$ & 0.1457 \\
\hline
\end{tabular}

Residual $=0.7131, * \& * *$ Showed significant at $5 \%$ \& $1 \%$ level of significance respectively, The bold figures denote the direct effect of different factors on population of pest

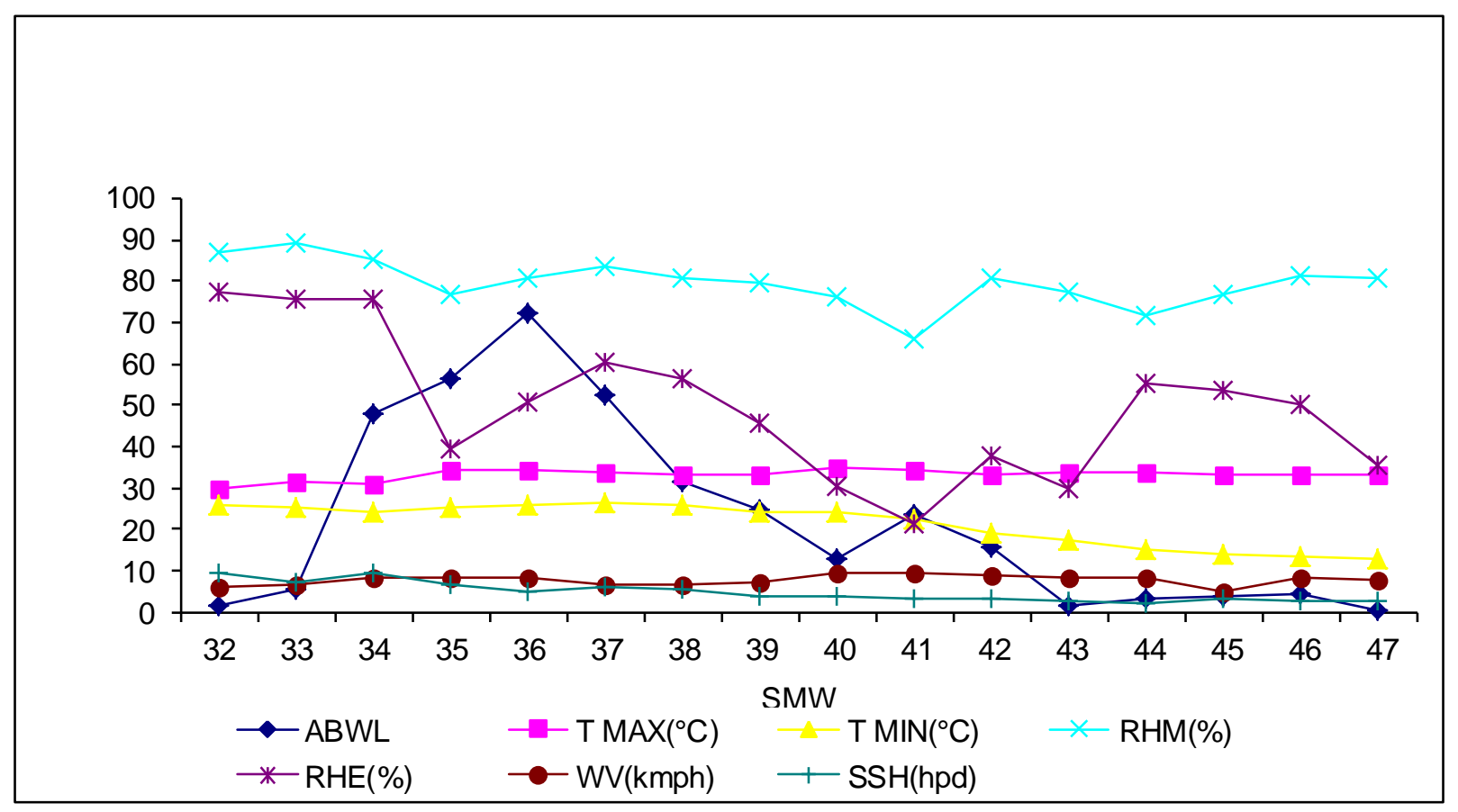

Fig.1 Climatic factors affect the population of American bollworm 


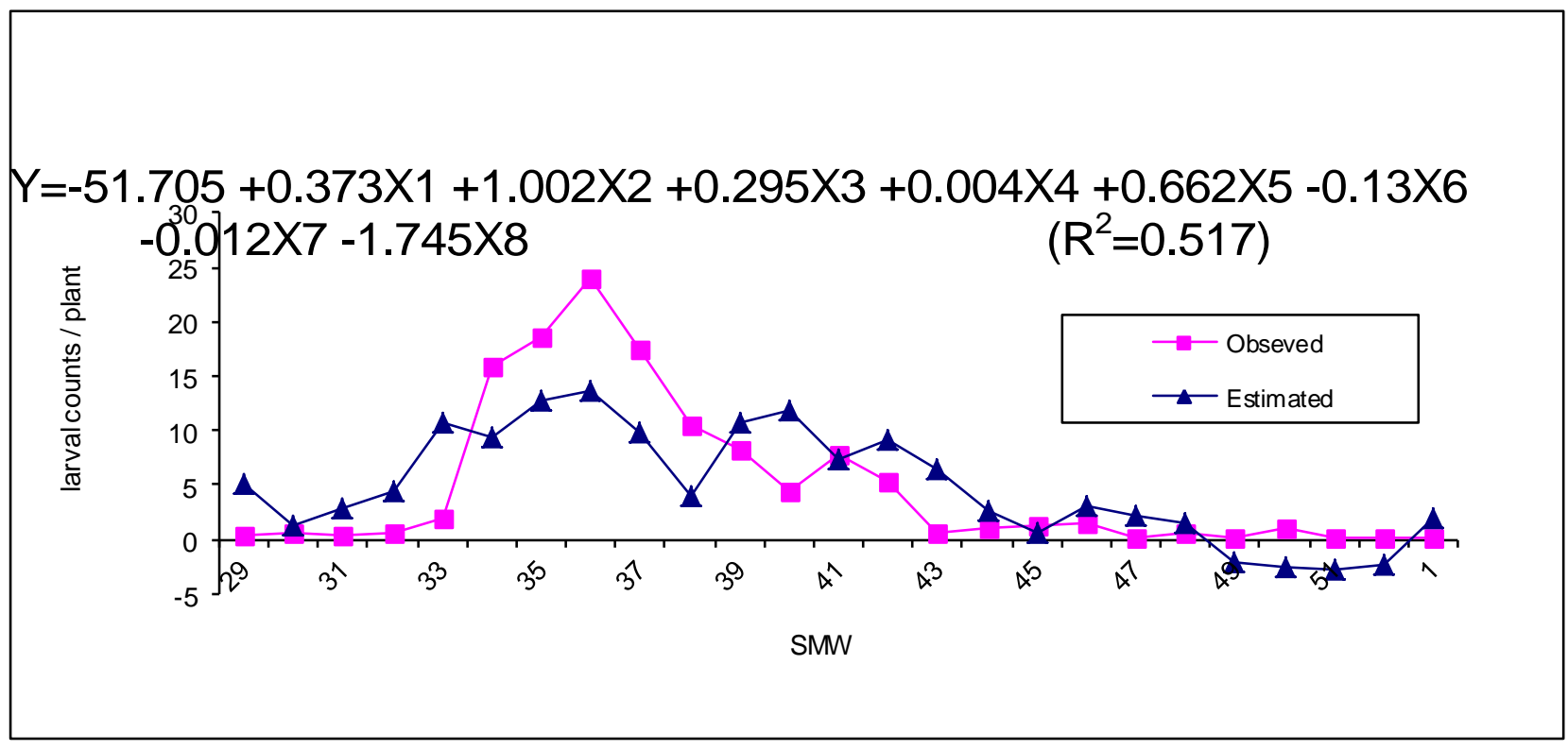

Fig.2 Mulltiple regession of certain factors on American bollworm larva population (Pooled)

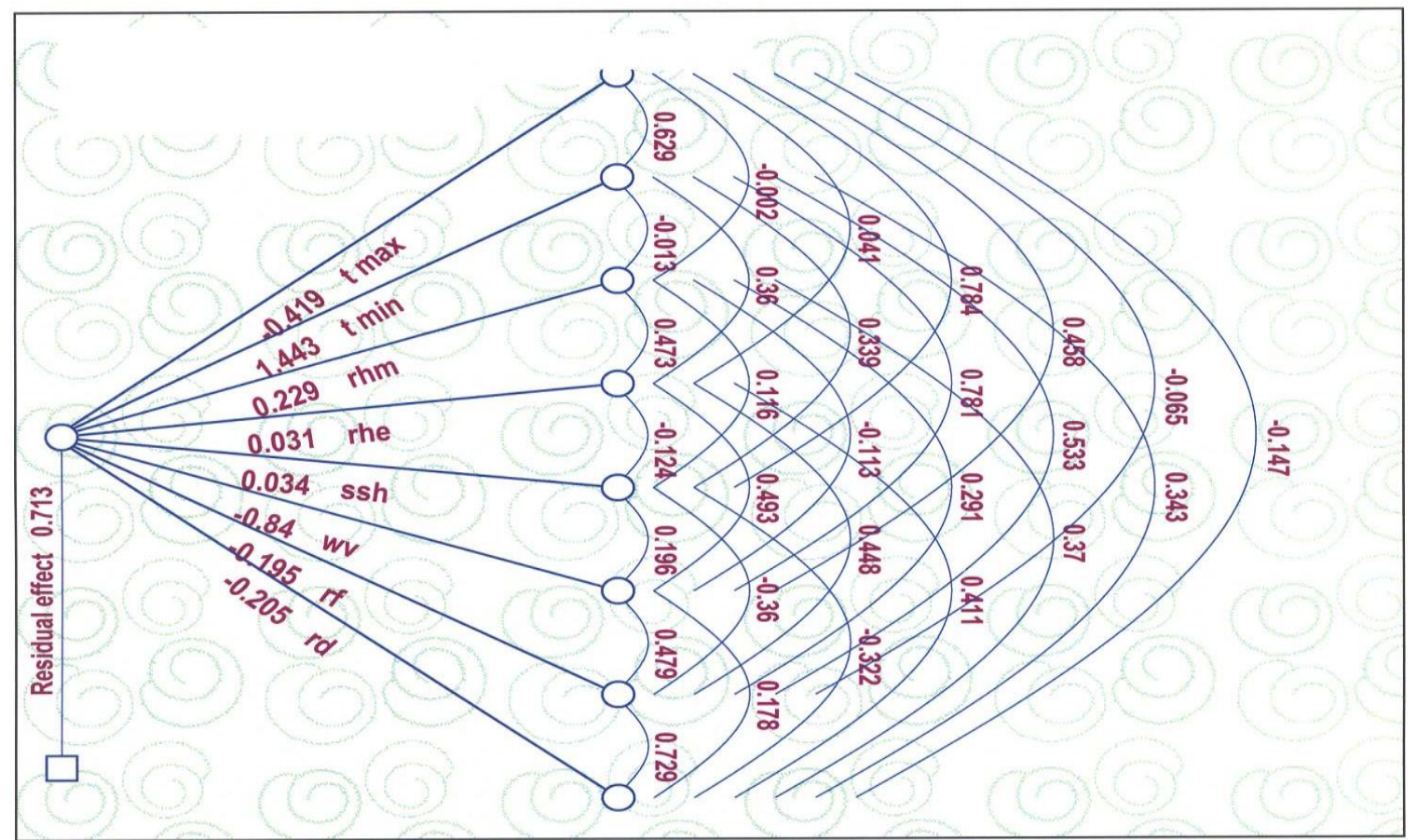

Fig.3 Path analysis showing influence of various factors on the population of ABW

Path coefficient effect revealed that the positive indirect effect of high magnitude of minimum temperature was obtained via, sun shine hours $(0.0 .113)$ and evening relative humidity (0.0110) respectively. Positive indirect effect of morning relative humidity was obtained wind velocity (0.0946), evening relative humidity $(0.0145)$, sunshine hours (0.0039) and maximum temperature (0.0007). Positive indirect effect of sun shine hours was obtained minimum temperature (0.4887), rainfall (0.0702), rainy days (0.0658) and morning relative humidity (0.0267). Path coefficient effect also revealed that the 
positive indirect effect of evening relative humidity was obtained morning relative humidity (0.1083) and minimum temperature (0.5199).

\section{References}

Bishnoi, O.P.; Mohan, Singh, Rao.; Vum, Ram, Niwas,; Sharma Singh, P.D. and Niwas, R (1996). Population dynamics of cotton pest in relation to weather parameters. Indian journal of Entomology. 58(2):103-107.

Gomez, K.A. and Gomez, A.A. (1984). Statistical Procedures for Agricultural Research (IInd edition), An International Rice Research Institute, A wiba -International publication, John willey and sons, New York. Pp. 680.

Hargreaves,H. (1948). List of recorded cotton insects of the world. commonwealth Inst.of Ent. London: 1-50.

Jawalkar, S.C.; Daware, D.G.; Awaz,H.B.; Badgujar, M.P. (2004) Incidence of American bollworm (Helicoverpa armigera) (Hub.) and its relation with ecological factors. Journal of Maharashtra Agricultural Universities; 29(1): 97-99.

Mohapatra, L.N.; Senapati, B.; Sahu, B.B.
(2004). Influence of weather factors on the incidence of cotton bollworms. Indian Journal of Entomology 66(1): 85-87.

Panse, V.G. and Sukhatme, P.V. (1985). Statistical methods for Agricultural Research. ICAR, New Delhi.

Pawar, C.S; Srivastava, C.P. and Reed,W. (1984). Some aspects of population dynamics of $H$. armigera Hubner. Paper presented in III Oriental Entomology Symposium, 21-24, Feb. at Univ. of Kerala, Kariavattom, Kerala, India. pp: $1-9$.

Rainwater, C.F.(1952). Progress in research on cotton insects. U.S.D.A. Yearb Agric. pp: 497-500.

Shahzad, M.K.; Shah, Z.A. and Anjum, S. (2003) Population dynamics of gram pod borer (Helicoverpa armigera), gram aphid (Aphis craccivora) and cotton aphid (Aphis gossypii) in relation to climatic conditions. Pakistan Entomologist 25(1): 77-84.

Singh, P.B.; Paul, A.V.N. and Gupta, G.P. (2005). Relationship of some generalist predators with their prey plants and prey insects. Annals of Plant Protection Sciences 13(1): 213-215.

\section{How to cite this article:}

Yogesh Patel and Garg, V. K. 2020. Path Analysis of Climatic Factors Affects the Population of American Bollworm, Helicoverpa armigera (Hubner) Lepidoptera - Noctuidae in Cotton. Int.J.Curr.Microbiol.App.Sci. 9(04): 1671-1676. doi: https://doi.org/10.20546/ijcmas.2020.904.195 